\title{
SAR Evaluation of Disubstituted Tacrine Analogues as Promising Cholinesterase and Carbonic Anhydrase Inhibitors
}

\author{
Salih Ökten ${ }^{1, \star}$, Makbule Ekiz², Ahmet Tutar², Burcu Bütün³ ${ }^{3}$ Ümit Muhammet Koçyiğit ${ }^{4}$, Gülaçtı Topçu ${ }^{5}$ \\ İlhami Gülçin ${ }^{6}$
}

${ }^{1}$ Department of Maths and Science Education, Faculty of Education, Kırıkkale University, Yahşihan, Kırıkkale, TURKEY. ${ }^{2}$ Department of Chemistry, Faculty of Art and Science, Sakarya University, Serdivan, 54187, Sakarya, TURKEY.

${ }^{3}$ Department of Pharmaceutical Chemistry, Faculty of Pharmacy, Bezmialem Vakif University, 34093, İstanbul, TURKEY. ${ }^{4}$ Department of Medical Techniques, Vocational School of Health Services, Cumhuriyet University, 58140, Sivas, TURKEY. ${ }^{5}$ Department of Pharmacognosy/Phytochemistry, Faculty of Pharmacy, Bezmialem Vakif University, 34093, İstanbul, TURKEY. ${ }^{6}$ Department of Chemistry, Faculty of Science, Atatürk University, 25240 Erzurum, TURKEY.

\begin{abstract}
Background: The inhibition of both hydrolysis products of acetylcholine (ACh), Acetylcholinesterase (AChE) and Butyrylcholinesterase (BChE), is essential for successful treatment of Alzhemier patients. Objectives: This study was investigated inhibition potentials of recently synthesized disubstituted tacrines derivatives on going our research against $\mathrm{AChE}, \mathrm{BChE}$ and carbonic anhydrase cyctosolic (hCA I and II) enzymes to explore the Structure activity relationship (SAR). Methods: Inhibitory activities of tested compounds against $\mathrm{AChE}$ and $\mathrm{BChE}$ were measured by spectrophotometric method, developed by Ellman et al. Furthermore, the disubstituted tacrines were determined as inhibitors of two physiologically relevant CA isoforms, the cytosolic hCA I and II by an esterase assay method. Results: The silyl, thiomethyl and cyano substituted seven membered hydrocycle tacrines $(9,11$ and 14) significantly inhibited AChE, compared with starting compound 3 (6,8-dibromo-2,3,4,5-teytrahydro-1H-cyclohepta[1,2-b] quinoline) and reference compounds, galantamine and tacrine, while methoxy substituted seven membered hydrocycle tacrine derivative 10 showed selective inhibition against $\mathrm{BChE}\left(\mathrm{IC}_{50}=563 \mathrm{nM}\right)$. Interestingly, disubstituted tacrines displayed higher or parallel inhibition to galantamine. Additionally, all these tacrine analogues were recorded to be powerful inhibitor compounds of the cytosolic isoenzyme hCA I with $\mathrm{K}_{\mathrm{i}}$ in the range of 43.81-471.67 nM, as well as a moderate selectivity toward hCA II isoenzyme with $\mathrm{K}_{\mathrm{i}}$ in the range from 87.14 to $614.68 \mathrm{nM}$ compared with AZA, as standard. Conclusion: The disubstituted seven membered hydrocycle tacrine analogues 9-12 and 14 may have promising anti Alzhemier drug candidate and dibromo six membered hydrocycle 2 and dibromo seven membered hydrocycle $\mathbf{3}$ derivatives may be novel hCA I and II enzyme inhibitors.
\end{abstract}

Key words: Tacrine derivatives, Acetylcholinesterase, Butyrylcholinesterase, Carbonic anhydrase, Anticholinegic, SAR.

\section{INTRODUCTION}

Alzheimer's disease (AD) is characterized as a neurological disorder and considered as lack of cognitive abilities in the elderly people. ${ }^{1} \mathrm{AD}$ starts with loss of memory accompanied by an increase of AChE activity that leads to run out of cholinergic and noncholinergic neurons in the brain.
Amyloid beta-protein plaques which form in the brain, are degradation product of Cholinesterase enzyme (ChE). ${ }^{2}$ There are several suggestions to the treatment of AD. The most preferred medication is discovery of either new cholinesterase inhibitors (alternative to donepezil, rivastigmine,
Submission Date: 03-07-2018; Revision Date: 31-10-2018; Accepted Date: 29-12-2018

DOI: 10.5530/ijper.53.2.35 Correspondence: Dr. Salih Ökten, Department of Maths and Science Education, Faculty of Education, Kırıkkale University, Yahşihan, Kırıkkale, TURKEY.

Phone: +90 31835742421394

E-mail: salihokten@kku. edu.tr

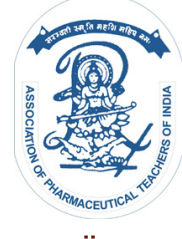

www.ijper.org 
tacrine and galanthamine) or N-methyl-D aspartate (NMDA) receptor antagonists such as memantine. ${ }^{3}$ Adverse effects of some synthetic acetylcholinesterase inhibitors used for the treatment of $\mathrm{AD}$ such as tacrine and donepezil, leads to reseachers to find innocent and most potent derivatives of these drugs. ${ }^{4-5}$ Therefore, it is very important to find new substances, more efficient and less expensive than the currently used drugs.

Tacrine was the first AChE inhibitor to be launched and approved by FDA as an $\mathrm{AD}$ drug. ${ }^{6}$ However, it exhibited several adverse effects which in some cases led to several problems. ${ }^{7}$ Due to that, many other AChE inhibitors have been studied and researchers have still continued to improve the pharmacological profile of the novel drug candidate. ${ }^{1,8}$ There are restricted reports about the synthesis of substituted tacrine displayed AChE inhibitory activity. Some reported studies showed halogenated tacrine analogues have better inhibitory activity compared with unsubstituted one. ${ }^{1}$ In a work, the high inhibition of a set of 6-and 7-substituted with $\mathrm{Cl}$ and $\mathrm{F}$ atoms 9-amino-1,2,3,4-tetrahydroacridine-1-ols were determined. In a theoretical work, it was concluded that $\mathrm{Cl}$ atom at C-6 of tacrine increased the binding strength to AChE probably due to its electron withdrawing effect. ${ }^{10}$

Carbonic anhydrase (CA, E.C.4.2.1.1) enzymes significantly exist in red blood cells and gastrointestinal tract of vertebrates and are class of zinc enzymes which perform catalyzing the reversible hydration of $\mathrm{CO}_{2}$ into protons and $\mathrm{HCO}_{3}^{-}$under physiological situations ${ }^{21}$ and exist in blood $\mathrm{pH}$ homeostasis and play a key role in $\mathrm{CO}_{2}$ transport to the lung cells. ${ }^{12,13} \mathrm{CA}$ inhibitors (CAIs) have recently been common studying area due to their significant applications for the treatment and prevention of an extensive number of diseases. The inhibition and activation effects of CA by many chemicals and drugs have been reported in the literature. ${ }^{14}$ At least $16 \mathrm{CA}$ isoforms were defined up to present in mammals, the scads active ones as catalyst agents for $\mathrm{CO}_{2}$ hydration being CA II and IX. ${ }^{15,16}$ Additionally, the realization of the physiological outcomes of inhibiting particular CA isoforms is developing as the science base about subcellular positions building CA enzymes kinetics, expression levels and tissue repartition. Most of these isoforms have shown promise as medication aims with CAs now involved in regions where human treatments are extremely needed, for example, obesity-specific (CA V) pathways, in cancer-specific (CA IX and XII) and in brain function (CA XIV). ${ }^{16-17}$

Our group recently reported the preparation of novel disubstituted tacrine derivatives, including five, six and seven membered hydrocycles, ${ }^{18}$ through cyclodehydration reaction of several ketones and 2-amino-3,5-dibromoben- zonitrile via Friedlander reaction furnished a series of dibromo tacrines. Then, bromo tacrine analogues were converted to corresponding disubstituted tacrine analogues by metal catalyzed or metal halogen exchange. The present work is a continuation of our ongoing research. ${ }^{18}$ Due to having the AChE inhibition potential of the tricyclic structure of the 1,2,3,4-tetrahydroacridine nucleus, we focused on investigation of anticholinergic activities of recently reported disubstituted tacrine as potential AChE, BChE, hCA I and hCA II inhibitors. Furthermore, to fill the gap in the SAR of substituted tacrine we focused on our work on tricyclic tacrine based AChE, BChE, hCA I and II inhibitors ${ }^{19-20}$ by testing a series of disubstituted tacrine analogues. The $\mathrm{IC}_{50}$ values for the inhibition of $\mathrm{AChE}$ and $\mathrm{BChE}$ were studied by means of SAR approach, in search for describing the dependence of AChE, BChE, hCA I and hCA II inhibitory activity on substituents of tacrine cycles.

\section{MATERIALS AND METHODS}

\section{Chemistry}

The synthesis of dibromo (1-5) tacrines via Friedländer reactions and disubstituted (7-14) tacrine derivatives via metal assisted electrophilic and nucleophilic substituted reactions and MeI salt form (6) of unsubstituted tacrine were reported recently by our previous publications. ${ }^{18,21}$ The isolated compounds (1-14) were fully characterized with melting point, HRMS analysis, infrared, ${ }^{1} \mathrm{H},{ }^{13} \mathrm{C}$, HMBC and HETCOR spectroscopy in this paper. ${ }^{18}$ This study was carried out with disubstituted tacrine derivatives (1-14) according to our previous paper. ${ }^{18,21,22}$

\section{Anticholinesterase Activity Assays}

The inhibitory efficacy of disubstituted tacrine derivatives (1-14) on BChE/AChE activities was obtained conforming to the spectrophotometric Ellman's procedure. ${ }^{23}$ Butrylcholine iodide (BChI) and also acetylthiocholine iodide (AChI) compounds were used as substrates of the both reactions..$^{24}$ In this part, 5,5'-dithio-bis(2-nitrobenzoic)acid (DTNB) was used for the estimation of the BChE/AChE activities. ${ }^{24}$ Briefly, $130 \mu \mathrm{L}$ of buffer solution ( $\mathrm{pH}$ 8.0, Tris/ $\mathrm{HCl}, 100 \mathrm{mM}$ ) and diverse concentration of sample solutions $(50-200 \mu \mathrm{L})$ dissolved in deionised water were added to $50 \mu \mathrm{L}$ of BChE/ AChE solutions. Then, the mixture was incubated for $15 \mathrm{~min}$ at $25^{\circ} \mathrm{C}$. Finally, $50 \mu \mathrm{L}$ of DTNB $(0.5 \mathrm{mM}$ and $25 \mathrm{~mL}$ ) of BChI/AChI was added to incubated mixture. Also, the reaction was initiated by the addition of $50 \mu \mathrm{L}$ of BChI/AChI. The activities of these enzymes were evaluated spectrophotometrically at a wavelength of $412 \mathrm{~nm} .{ }^{25}$ The butyrylcholinesterase enzyme obtained from Equus caballus and acetylcholinesterase enzyme 
isolated from Electrophorus electricus were obtained from market. Galantamine and Tacrine compounds were used as control compound. Ethanol was used as a solvent to dissolve test compounds and the controls. The anticholinesterase activity of the fourteen tacrine derivatives were measured at different concentrations $\left(10^{-8}-200 \mu \mathrm{M}\right)$ for calculation of the $\mathrm{IC}_{50}$ values. Each substance was tested three times in triplicate against $\mathrm{AChE}$ and BChE enzymes.

The percentage of inhibition of $\mathrm{AChE}$ or $\mathrm{BChE}$ was determined by a comparison of the rates of reaction of samples relative to blank sample (ethanol in phosphate buffer $\mathrm{pH}$ 8) using the formula;

$$
[(\mathrm{E}-\mathrm{S}) / \mathrm{E}] \times 100
$$

where $\mathrm{E}$ is the activity of enzyme without test sample and $\mathrm{S}$ is the activity of enzyme with test sample.

\section{Carbonic anhydrase I and II isoenzymes purification and inhibition studies}

The purification of both cytosolic CA isoforms (hCA I and II) of human blood cells was previously explained with a simple one-step procedure by a Sepharose-4B-LTyrosine-sulphanilamide affinity chromatography as described previously. ${ }^{26}$ The protein quantity in the column effluents was evaluated spectrophotometrically at $280 \mathrm{~nm}$ previously described. For purification of both isoenzymes, sodium dodecyl sulfate-polyacrylamide gel electrophoresis (SDS-PAGE) was applied. CA isoenzymes activities were obtained in conforming to Verpoorte procedure ${ }^{27}$ explained previously in details. ${ }^{28}$ Increasing absorbance of the reaction medium was spectrophotometrically obtained at $348 \mathrm{~nm}$. We utilized the esterase activity procedure for ascertaining the inhibition agents by the Lineweaver-Burk procedure. ${ }^{29} \mathrm{CA}$ activity $(\%)$ versus inhibitory concentration and $1 / \mathrm{V}$ versus $1 /[\mathrm{S}]$ graphs were drawn. The quantity of protein was determined at $595 \mathrm{~nm}$ according to Bradford's procedure. ${ }^{30}$ Bovine serum albumin was used as standard protein. ${ }^{31}$ For the designation of the inhibition efficacy of each novel disubstituted tacrine derivatives on both hCA isoenzymes, an activity (\%)-[disubstituted tacrine derivatives] graph was drawn. The $\mathrm{IC}_{50}$ values were obtained from activity (\%) versus compounds plots. For the calculation of $\mathrm{K}_{\mathrm{i}}$ values, disubstituted tacrine derivatives concentrations were used.

\section{RESULTS}

\section{Chemistry}

In our previous papers, ${ }^{18,21-22}$ one-pot synthesis was described for bromo tacrine derivatives (1-5) (Figure 1)

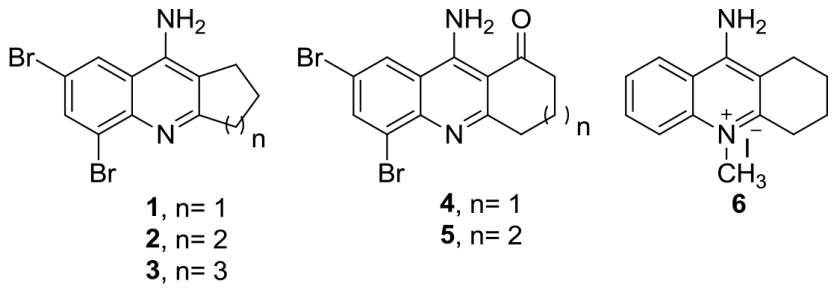

Figure 1: Structures of bromotacrine derivatives (1-5) and methyliodine salt form tacrine (6)

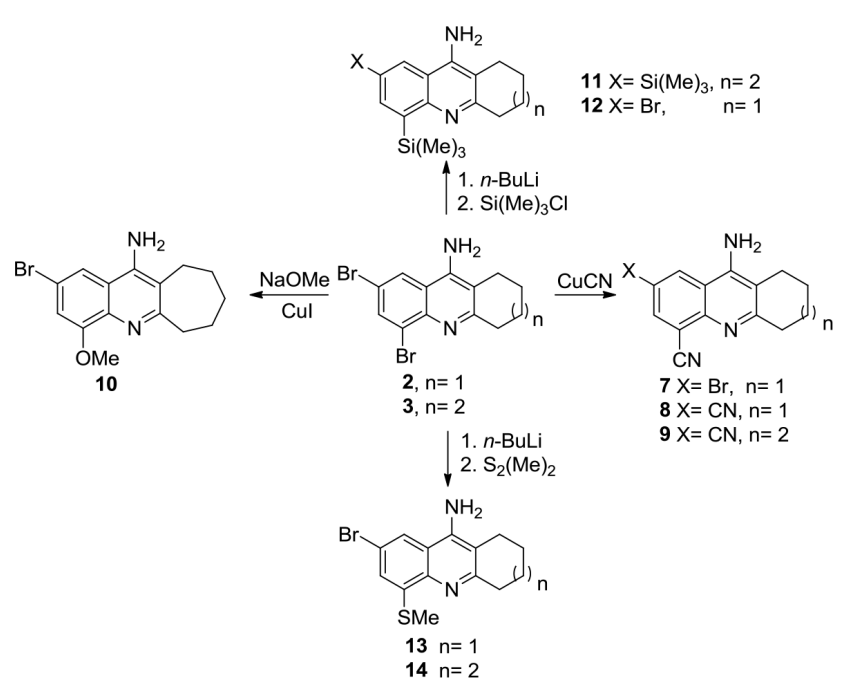

Scheme 1: Synthesis of disubstituted tacrine derivatives (7-14)

using Friedländer reactions of several cyclic ketones and brominated 2-amino-3,5-dibromobenzonitrile (17) in the presence of some Lewis acids. To achieve the direct bromination, tacrine was treated to methyl iodine to protect of the $N$ atom in the cycle. This reaction furnished the methyl iodine salt form (6) of unsubstituted tacrine.

Tacrine bromides were converted corresponding thiomethyl (13-14) and silyl (11-12) derivatives by the treatment of dibromo 1 and 2 derivatives with $n$-BuLi followed by trapping with an electrophile [ $\left.\mathrm{Si}(\mathrm{Me})_{3} \mathrm{Cl}, \mathrm{S}_{2}(\mathrm{Me})_{2}\right]$ (Scheme 1). Copper-assisted nucleophilic substitution reactions of brominated tacrines furnished cyano (7-9 and methoxide (10) derivatives (Scheme 1). ${ }^{18}$

\section{Anticholinesterase activity results}

Tacrine (THA, 1,2,3,4-tetrahydroacridine) is one of the most important inhibitor of both $\mathrm{AChE}$ and $\mathrm{BChE}$ enzymes. ${ }^{42,32-34}$ Despite the lack of its selectivity and hepatotoxicity and limitation of its medical therapy, tacrine remains a reference compound $\left(\mathrm{IC}_{50}=59 \mathrm{nM}\right.$ for $\mathrm{AChE}$ and $\mathrm{IC}_{50}=23 \mathrm{nM}$ for $\mathrm{BChE}$, taken in our study) in the design and development of promising ChEs inhibitors candidates. The high AChE and BChE 
inhibitory feature of tacrine has encouraged us to development of the effective tacrine derivatives.

We have just reported the inhibition potential of disubstituted tacrine derivatives against $\mathrm{AChE}$ and $\mathrm{BChE}$ as $\mathrm{IC}_{50}$ values in Table 1 . The inhibitory activities of tested molecules are compared with unsubstituted tacrine and galatamine $\left(\mathrm{IC}_{50}=1280 \mathrm{nM}\right.$ for $\mathrm{AChE}$ and $\mathrm{IC}_{50}=19530 \mathrm{nM}$ for BChE, taken in our study) as standard compound.

The disubstituted tacrine derivatives were showed to be potent inhibitor compounds of cholinesterases with $\mathrm{IC}_{50}$ values in nanomolar concentration scale. The excellent AChE inhibitor in the assayed series of disubstituted tacrine is dicyano substituted seven membered hydrocycle tacrine 9 with $\mathrm{IC}_{50}=68 \mathrm{nM}$. The compound 11 has selectivity to $\mathrm{AChE}$ than $\mathrm{BChE}$ comparison to standard compounds galantamine and tacrine. Also, disilyl $11\left(\mathrm{IC}_{50}=454 \mathrm{nM}\right)$ and thiomethyl $14\left(\mathrm{IC}_{50}=405 \mathrm{nM}\right)$ seven membered hydrocycle tacrines and monosilyl 12 $\left(\mathrm{IC}_{50}=233 \mathrm{nM}\right)$ six membered hydrocycle tacrine significantly inhibited AChE enzyme. The compounds 9,
11, 12 and 14 proved to be the most selective AChE inhibitor. Also these compounds are more selective than galantamine and unsubstituted tacrine. The substituted tacrine derivatives, except of compounds $2\left(\mathrm{IC}_{50}=6140\right.$ $\mathrm{nM}), \mathbf{4}\left(\mathrm{IC}_{50}=8480 \mathrm{nM}\right)$ and $\mathbf{5}\left(\mathrm{IC}_{50}=7460 \mathrm{nM}\right)$ showed good inhibition as galantamine against $\mathrm{AChE}$ in a range of $68-3780 \mathrm{nM}$.

To the $\mathrm{BChE}$ inhibition results, among the all tacrine derivatives, methoxy substituted seven membered tacrine $\mathbf{1 0}$ was the most active and more selective in inhibiting $\mathrm{BChE}$ in $\mathrm{IC}_{50}$ of $536 \mathrm{nM}$. Despite the high inhibition of 10 against $\mathrm{BChE}$ enzyme, this compounds moderately inhibited AChE enzyme. Moreover, all compounds, except of 11, have good inhibitory effect against to $\mathrm{BChE}$ compared with galantamine as standard and clinical cholinergic enzymes inhibitor. It was interested that compound $\mathbf{1 1}$ significantly inhibited to AChE with $\mathrm{IC}_{50}$ value of $454 \mathrm{nM}$ while it was not active against BChE (Table 1).

These results indicated that the position and kinds of substituents are important to anti $\mathrm{AChE}$ and $\mathrm{BChE}$

\section{Table 1: AChE and BChE inhibitory activity $\left(\mathrm{IC}_{50}\right)$ of the disubstituted tacrine derivatives.}

\begin{tabular}{|c|c|c|c|c|c|c|c|c|}
\hline & & & & $\mathrm{R}_{2}$ & 1 & & & \\
\hline Comp. & $n$ & $\mathbf{R}_{1}$ & $\mathbf{R}_{2}$ & Bounded other groups & $\begin{array}{c}\text { AChE } \\
\mathrm{IC}_{50} \pm \mathrm{SD} \\
(\mathrm{nM})\end{array}$ & $r^{2}$ & $\begin{array}{c}\text { BChE } \\
I_{50} \pm S D(n M)\end{array}$ & $r^{2}$ \\
\hline 1 & 1 & $\mathrm{Br}$ & $\mathrm{Br}$ & - & $1890 \pm 530$ & 0.996 & $2080 \pm 670$ & 0.992 \\
\hline 2 & 2 & $\mathrm{Br}$ & $\mathrm{Br}$ & - & $6140 \pm 148$ & 0.998 & $6930 \pm 1720$ & 0.999 \\
\hline 3 & 3 & $\mathrm{Br}$ & $\mathrm{Br}$ & - & $3780 \pm 201$ & 0.999 & $4280 \pm 161$ & 0.999 \\
\hline 4 & 2 & $\mathrm{Br}$ & $\mathrm{Br}$ & Ketone form at $\mathrm{C} 1$ & $8480 \pm 836$ & 0.994 & $11140 \pm 658$ & 0.996 \\
\hline 5 & 3 & $\mathrm{Br}$ & $\mathrm{Br}$ & Ketone form at $\mathrm{C} 1$ & $7460 \pm 502$ & 0.997 & $6400 \pm 181$ & 0.999 \\
\hline 6 & 2 & $\mathrm{H}$ & $\mathrm{H}$ & Mel salt form at $N$ of ring & $1470 \pm 358$ & 0.990 & $1860 \pm 103$ & 0.987 \\
\hline 7 & 2 & $\mathrm{Br}$ & $\mathrm{CN}$ & - & $2980 \pm 640$ & 0.999 & $4740 \pm 810$ & 0.993 \\
\hline 8 & 2 & $\mathrm{CN}$ & $\mathrm{CN}$ & - & $2750 \pm 320$ & 0.998 & $2360 \pm 118$ & 0.994 \\
\hline 9 & 3 & $\mathrm{CN}$ & $\mathrm{CN}$ & - & $68 \pm 12.3$ & 0.999 & $3720 \pm 208$ & 0.984 \\
\hline 10 & 3 & $\mathrm{Br}$ & $\mathrm{OCH}_{3}$ & - & $2340 \pm 240$ & 0.989 & $563 \pm 32.5$ & 0.999 \\
\hline 11 & 3 & $\mathrm{Si}\left(\mathrm{CH}_{3}\right)_{3}$ & $\mathrm{Si}\left(\mathrm{CH}_{3}\right)_{3}$ & - & $454 \pm 23.5$ & 0.999 & $732520 \pm 3540$ & 0.999 \\
\hline 12 & 2 & $\mathrm{Br}$ & $\mathrm{Si}\left(\mathrm{CH}_{3}\right)_{3}$ & - & $233 \pm 11.8$ & 0.982 & $9100 \pm 260$ & 0.996 \\
\hline 13 & 2 & $\mathrm{Br}$ & $\mathrm{SCH}_{3}$ & - & $2010 \pm 470$ & 0.992 & $2030 \pm 530$ & 0.998 \\
\hline 14 & 3 & $\mathrm{Br}$ & $\mathrm{SCH}_{3}$ & - & $405 \pm 22.1$ & 0.986 & $2980 \pm 129$ & 0.998 \\
\hline \multicolumn{5}{|c|}{ Tacrine (Reference Compound A) } & $59 \pm 14.7$ & 0.999 & $23 \pm 10.6$ & 0.999 \\
\hline \multicolumn{5}{|c|}{ Galantamine (Reference Compound B) } & $2280 \pm 106$ & 0.997 & $19530 \pm 1740$ & 0.999 \\
\hline
\end{tabular}




\begin{tabular}{|c|c|c|c|c|c|c|}
\hline \multirow{2}{*}{ Compounds } & \multicolumn{4}{|c|}{$\mathrm{IC}_{50}(\mathrm{nM})$} & \multicolumn{2}{|c|}{$\mathrm{K}_{\mathrm{i}}(\mathrm{nM})$} \\
\hline & hCA I & $r^{2}$ & hCA II & $r^{2}$ & hCA I & hCA II \\
\hline 1 & 358.51 & 0.9996 & 500.36 & 0.9329 & $300.04 \pm 7.51$ & $554.36 \pm 228.18$ \\
\hline 2 & 76.15 & 0.9628 & 99.06 & 0.9440 & $111.76 \pm 45.03$ & $114.44 \pm 51.05$ \\
\hline 3 & 33.03 & 0.9877 & 85.77 & 0.9615 & $43.81 \pm 11.98$ & $87.14 \pm 34.23$ \\
\hline 6 & 408.12 & 0.9880 & 551.75 & 0.9330 & $380.15 \pm 90.21$ & $614.68 \pm 153.91$ \\
\hline 7 & 379.11 & 0.9973 & 563.86 & 0.9712 & $330.17 \pm 108.95$ & $603.43 \pm 227.47$ \\
\hline 8 & 392.85 & 0.9827 & 565.71 & 0.9437 & $303.31 \pm 61.82$ & $434.51 \pm 200.98$ \\
\hline 9 & 414.22 & 0.9522 & 460.46 & 0.9631 & $315.04 \pm 48.37$ & $454.08 \pm 147.66$ \\
\hline 10 & 443.66 & 0.9814 & 462.92 & 0.9593 & $471.67 \pm 201.35$ & $422.58 \pm 161.62$ \\
\hline 11 & 354.31 & 0.9813 & 420.76 & 0.9707 & $297.63 \pm 40.02$ & $421.26 \pm 99.96$ \\
\hline 12 & 389.54 & 0.9805 & 456.82 & 0.9728 & $320.67 \pm 24.34$ & $424.23 \pm 83.54$ \\
\hline 13 & 399.65 & 0.9776 & 474.65 & 0.9461 & $382.60 \pm 93.32$ & $509.73 \pm 182.84$ \\
\hline 14 & 412.52 & 0.9863 & 475.31 & 0.9695 & $323.21 \pm 85.56$ & $455.12 \pm 94.14$ \\
\hline$A Z A$ & 3745.94 & 0.9653 & 3347.82 & 0.9899 & $3320.46 \pm 716.02$ & $718.92 \pm 531.18$ \\
\hline
\end{tabular}

activities, especially silyl and cyano substituted seven membered hydrocycle tacrines showed the highest AChE inhibitory activity compared with bromo tacrine analogues and galantamine. Also, these compounds showed to close to unsubstituted tacrine's inhibitory activity against AChE (Table 1).

\section{Carbonic anhydrases inhibition activity results}

The disubstituted tacrine derivatives reported here were determined as inhibitors of two physiologically relevant CA isoforms, the cytosolic hCA I, hCA II by an esterase assay method. ${ }^{35,36}$ Acetazolamide (AZA), a clinically used sulfonamide CAI was used in the assays as a standard drug. The results are shown in Table $2\left(\mathrm{IC}_{50}\right.$ and $\mathrm{K}_{\mathrm{i}}$ values expressed as nanomolar (nM)). This study clearly indicated that disubstituted tacrine derivatives (1-3, 7-14) and its methyliodine salt form (6) showed good hCA I and hCA II inhibitory effects. The slow cytosolic isoform hCA I (take part in important physiological and pathological processes in many tissues and organs), was significantly inhibited by most of the disubstituted tacrine derivatives with $K_{\mathrm{i}}$ s ranging between 43.81 and $471.67 \mathrm{nM}$. The best inhibitions for this isoform were determined by dibromo six membered 2 and dibromo seven membered 3 tacrine derivatives, with $K_{i}$ values of 111.76 and $43.81 \mathrm{nM}$, respectively. Additionally, acetazolamide (AZA) as sulphonamide compound was recorded for broad-specificity CA inhibitor which obtained $\mathrm{K}_{\mathrm{i}}$ value of $3320.46 \mathrm{nM}$ against hCA I.

CA II is often associated with several diseases such as glaucoma, osteoporosis and renal tubular acidosis. ${ }^{37}$ For
hCA II, disubstituted tacrine derivatives (1-3, 7-14) had $\mathrm{K}_{\mathrm{i}}$ values from 87.14 to $614.68 \mathrm{nM}$. Moreover, AZA (5-aceta-mido-1,3,4-thiadiazole-2-sulfonamide), which is used for the treatment of altitude sickness, cystinuria, idiopathic intracranial hypertension, glaucoma, epileptic seizure, dural estasia and central sleep apnoea, had a medium potency hCA II inhibition for this isoform, ${ }^{38}$ with a $\mathrm{K}_{\mathrm{i}}$ value of $2718.92 \mathrm{nM}$. Also, dibromo six membered hydrocycle 2 and dibromo seven membered hydrocycle 3 tacrine derivatives have the highest inhibition effects against hCA II with $\mathrm{K}_{\mathrm{i}}$ values of 114.44 and $87.14 \mathrm{nM}$, respectively.

\section{DISCUSSION}

These compounds were defined in synthetically available position molecules of the aryl rings of tacrine analogues bearing six and seven membered hydrocycle as well as on primary amino group in order to evaluate the SAR mechanism of this series. The structural of disubstituted tacrine analogues of $\mathrm{AChE}$ and $\mathrm{BChE}$ enzymes inhibition data expressed as $\mathrm{IC}_{50}$ values in $\mathrm{nM}$ level which are shown in Table 1. Also hCA I and hCA II inhibitory potentials' data expressed as $\mathrm{IC}_{50}$ and $\mathrm{K}_{\mathrm{i}}$ values in $\mathrm{nM}$ concentrations are shown in Table 2.

It is evident that both nature and positions of the substituents at C-5 and C-7 for six membered hydrocycle tacrine and the substituents at C- 6 and C-8 for seven membered hydrocycle tacrine analogues are able to vary the $\mathrm{AChE}$ and $\mathrm{BChE}$ inhibition activity of tacrine. However, we did not observe the variation and selectivity 
of hCA I and hCA II inhibitory potentials of disubstituted tacrine derivatives. All compounds have good inhibitory effect of hCA I and hCA II enzymes, compared standard and clinical compound of AZA. Especially, 5,7-dibromo six membered hydrocycle tacrine 2 and 6,8-dibromo seven membered hydrocycle tacrine $\mathbf{3}$ showed the best inhibition against $\mathrm{hCA}$ I $\left(\mathrm{IC}_{50}=76.15\right.$ and $33.03 \mathrm{nM}$, respectively) and against hCA II $\left(\mathrm{IC}_{50}=99.06\right.$ and $85.77 \mathrm{nM}$, respectively).

The results of $\mathrm{AChE}$ and $\mathrm{BChE}$ inhibition activity, we introduced the electron attracting groups $\mathrm{CN}$ and $\mathrm{Br}$ and the electron donating groups, $\mathrm{Si}\left(\mathrm{CH}_{3}\right)_{3}, \mathrm{SCH}_{3}$ and $\mathrm{OCH}_{3}$ in positions of $\mathrm{C}-6$ and $\mathrm{C}-8$ of seven membered hydrocycle, C-5 and C-7 of six membered hydrocycle tacrines. The nitrile $(\mathrm{CN})$, silyl $\left(\mathrm{Si}\left(\mathrm{CH}_{3}\right)_{3}\right)$ and thiomethyl $\left(\mathrm{SCH}_{3}\right)$ substituents in seven membered hydrocycle tacrine (9, 11 and 14) increase the AChE inhibitory activity, compared with starting material $\mathbf{3}\left(\mathrm{IC}_{50}=3708 \mathrm{nM}\right)$. Despite these results, 9, $\mathbf{1 1}$ and $\mathbf{1 4}$ showed poor inhibitory activities against $\mathrm{BChE}$ inhitory activities, especially for compound $\mathbf{1 2}\left(\mathrm{IC}_{50}=732520 \mathrm{nM}\right)$ in Table 1. Similarly, silyl, electron donating group, at C-5 in six membered hydrocycle tacrine $11\left(\mathrm{IC}_{50}=233 \mathrm{nM}\right)$ significantly increased the inhibition activity against AChE enzyme. However, the other substituents in six membered hydrocycle tacrine, $\mathrm{Br}, \mathrm{CN}$ and $\mathrm{SCH}_{3}$ substituted at positions of $\mathrm{C}-5$ and $\mathrm{C}-7$, analogues $2,7,8,13$ showed moderate activity against $\mathrm{AChE}$ with $\mathrm{IC}_{50}$ ranging between 2010 and $6140 \mathrm{nM}$ and BChE enzymes with $\mathrm{IC}_{50}$ ranging between 2030 and $6930 \mathrm{nM}$, compared with galantamine $\left(\mathrm{IC}_{50}=2280 \mathrm{nM}\right.$ against $\mathrm{AChE}$, $\mathrm{IC}_{50}=19530 \mathrm{nM}$ against $\left.\mathrm{BChE}\right)$. Interestingly, the electron donating groups $\mathrm{SCH}_{3}$ and $\mathrm{OCH}_{3}$ in $\mathrm{C}-6$ position of seven membered hydrocycle tacrines display selective inhibitory activity. While the bromine changed with methoxide at C-6 of compound $\mathbf{1 0}$ blocked the increasing of BChE enzyme with $\mathrm{IC}_{50}=563 \mathrm{nM}$, thiomethyl at C-6 of compound 14 showed selectively AChE inhibitory activity with $\mathrm{IC}_{50}=405 \mathrm{nM}$. The bromine group in all dibromo tacrine derivatives (1-5) did not show significant inhibitory activity against $\mathrm{AChE}$ and $\mathrm{BChE}$ enzymes compared with unsubstituted one. The other interesting result is that tacrine in unsubstituted form, used as reference compound in anticholinergic studies, have excellent inhibition effect against $\mathrm{AChE}$ and $\mathrm{BChE}$ enzymes while the $\mathrm{AChE}\left(\mathrm{IC}_{50}=1470 \mathrm{nM}\right)$ and $\mathrm{BChE}$ $\left(\mathrm{IC}_{50}=1860 \mathrm{nM}\right)$ inhibitory activity of MeI salt form (6) of this compound significantly decreased, which is evidence that $N$ atom of tacrine in unsubstituted form could be responsible for inhibitory effect of tacrine against $\mathrm{AChE}$ and $\mathrm{BChE}$ enzymes. Moreover, the decreasing of inhibitory activity of MeI salt form (6) of this compound compared tacrine's inhibitory activity possibly may cause diminish some serious side effects of tacrine on $\mathrm{AD}$ patients because the cytotoxicity of MeI salt form of tacrine has promising acceptable results according to preresults of ongoing research.

\section{CONCLUSION}

In this work, disubstituted tacrine analogues, recently synthesized by our group, ${ }^{18,21}$ were found to be potent and selective inhibitors of $\mathrm{AChE}$ and $\mathrm{BChE}$ with $\mathrm{IC}_{50}$ in nanomolar concentration scale. Moreover, we investigated and assessed as inhibitors of two physiologically related and important $\mathrm{CA}$ isoforms, the cytosolic, hCA I and hCA II. Then, we attempted to determine the SAR of the effects of the introduction of substituents in some position of tacrine. The substituted seven membered hydrocycle tacrine analogues selectively showed the effective inhibitory activity against $\mathrm{AChE}$ and $\mathrm{BChE}$ enzymes. The cyano at C-6 and C-8, silyl at C-6 and C-8 and thiomethyl at C-6 substituted seven membered hydrocycle tacrine derivatives $(\mathbf{9}, 11$ and 14$)$ have the good inhibitions against $\mathrm{AChE}\left(\mathrm{IC}_{50}\right.$ in the range of 68-454 nM) while methoxy at C-6 substituted seven membered hydrocycle tacrine $\mathbf{1 0}$ showed the best inhibitory activity against $\mathrm{BChE}\left(\mathrm{IC}_{50}=563 \mathrm{nM}\right)$. All the disubstituted tacrine derivatives $(\mathbf{1 - 3}, \mathbf{6 - 1 4})$ used in the present study described effective inhibition profiles against both hCA isoenzymes compared with acetazolamide (AZA), which used as a medication used to treat glaucoma, altitude sickness, epilepsy, idiopathic intracranial hypertension, periodic paralysis and heart failure. ${ }^{39}$ In conclusion, disubstituted tacrine analogues, especially seven membered hydrocycle, have being a potential of cholinesterase enzymes inhibitor and both cytosolic CA isoenzymes. These results suggest that the dibromo tacrine derivatives may lead to synthesis of novel and effective CA inhibitors. In our ongoing research, we have been studing on cytotoxic profiles of substituted tacrine analogues in progress and we have obtained promising results. This present study and our ongoing research can contribute to the investigation of a cure for $\mathrm{AD}$ or therapy in the future.

\section{ACKNOWLEDGEMENT}

This study was supported by grants from the Sakarya University Research Fund (Project number: 2014-0204-008).

\section{CONFLICT OF INTEREST}

The authors declare no conflict of interest. 


\section{ABBREVIATIONS}

ACh: Acetylcholine; AChE: Acetylcholinesterase; BChE: Butyrylcholinesterase; SAR: Structure Activity Relationship; CA: Carbonic Anhydrase; AD: Alzheimer's disease; ChE: Cholinesterase Enzyme; A beta: Amyloid beta-protein; NMDA: N-methyl-D aspartate; FDA: Food and Drug Administration; HRMS: High Resolution Mass Spectroscopy; ${ }^{1} \mathbf{H}$ NMR: Proton Nuclear Magnetic Resonance Spectroscopy; ${ }^{13} \mathbf{C}$ NMR: Carbon 13 Nuclear Magnetic Resonance Spectroscopy; HMBC: Heteronuclear Multiple Bond Correlation; HETCOR: Heteronuclear Correlation; DTNB: 5,5'-Dithio-bis(2nitro-benzoic)acid; BChI: Butrylcholine Iodide: AChI: Acetylthiocholine Iodide; MeI: Methyl Iodide; SDSPAGE: Sodium Dodecyl Sulfate-Polyacrylamide Gel Electrophoresis; THA: Tacrine; IC $_{50}$ : The Half Maximal Inhibitory Concentration; $\mathbf{K}_{\mathbf{i}}$ : Inhibition Constant; AZA: Acetazolamide.

\section{REFERENCES}

1. Standridge JB. Pharmacotherapeutic approaches to the treatement of alzheimer's disease. Clin Ther. 2004;26(5):615-25.

2. Zheng WH, Bastianetto S, Mennicken F, Ma W, Kar S. Amyloid beta peptide induces tau phosphorylation and loss of cholinergic neurons in rat primary septal cultures. Neuroscience. 2002;115(1):201-11.

3. Hank FK. The $\beta$-amyloid hypothesis in alzheimer's disease: Seeing is believing. ACS Med Chem Lett. 2012;3:265-7.

4. Mukherjee PK, Kumar V, Mal M, Houghton PJ. Acetylcholinesterase inhibitors from plants. Phytomedicine. 2007;14(4):289-300.

5. Silva L, Rodrigues AM, Ciriani M, Falé PLV, Teixeira V, Madeira P, et al. Antiacetylcholinesterase activity and docking studies with chlorogenic acid, cynarin and arzanol from Helichrysum stoechas (Lamiaceae). Med Chem Res. 2017;26(11):2942-50

6. Cheng XM. To Market, To Market-1993. Ann Rep Med Chem. 1994;29:331.

7. Brinton RD, Yamazaki RS. Advances and challenges in the prevention and treatment of Alzheimer's disease. Pharm Res. 1998;29:331-4

8. Eghtedari M, Sarrafi $Y$, Nadri H, Mahdavi M, Moradi A, Moghadam FH. et al. New tacrine-derived AChE/BuChE inhibitors: Synthesis and biological evaluation of 5-amino-2-phenyl-4H-pyrano [2,3-b]quinoline-3-carboxylates. Eur J Med Chem. 2017;128:237-46.

9. Shutske GM, Pierrat FA, Kapples KJ, Cornfeldt ML, Szewczak MR, Huger FP. et al. 9-Amino-1,2,3,4-tetrahydroacridin-1-ols. Synthesis and evaluation as potential Alzheimer's disease therapeutics. J Med Chem. 1989;32(8):1805-13.

10. Wlodek ST, Antosiewicz J, McCammon JA, Straatsma TP, Gilson MK, Briggs JM. et al. Binding of tacrine and 6-chlorotacrine by acetylcholinesterase. Biopolymers. 1996;38(10):109-17.

11. Lolak N, Akocak S, Bua S, Koca M, Supuran CT. Design and synthesis of novel 1,3-diaryltriazene-substituted sulfonamides as potent and selective carbonic anhydrase II inhibitors. Bioorg Chem. 2018;77:542-7.

12. Koçyiğit ÜM, Aslan OM, Gülçin I, Temel Y, Ceylan M. Synthesis and carbonic anhydrase inhibition of novel 2-(4-(aryl)thiazole-2-yl)-3a, 4, 7, 7a-tetrahydro-1h-4, 7-methanoisoindole-1, 3 (2h)-dione derivatives. Arch Pharm. 2016;349(12):955-63.

13. Bayrak Ç, Taslimi P, Gülçin İ, Menzek A. The first synthesis of 4-phenylbutenone derivative bromophenols including natural products and their inhibition profiles for carbonic anhydrase, acetylcholinesterase and butyrylcholinesterase enzymes. Bioorg Chem. 2017;72:359-66.

14. Koçyiğit ÜM, Taslimi P, Gezegen H, Gülçin I, Ceylan M. Evaluation of acetylcholinesterase and carbonic anhydrase inhibition profiles of 1, 2, 3,
4, 6-pentasubstituted-4-hydroxy-cyclohexanes. J Biochem Mol Toxicol. 2017;31(9):e21938.

15. Öztaşkın N, Taslimi P, Maraş A, Göksu S, Gülçin I. Novel antioxidant bromophenols with acetylcholinesterase, butyrylcholinesterase and carbonic anhydrase inhibitory actions. Bioorg Chem. 2017;74:104-14.

16. Gülçin I, Abbasova M, Taslimi P, HuyutZ, Safarova L, SujayevA, et al. Synthesis and biological evaluation of aminomethyl and alkoxymethyl derivatives as carbonic anhydrase, acetylcholinesterase and butyrylcholinesterase inhibitors. J Enzyme Inhib Med Chem. 2017;32:1174-82.

17. Taslimi P, Akıncıoğlu H, Gülçin İ. Synephrine and phenylephrine act as a-amylase, a-glycosidase, acetylcholinesterase, butyrylcholinesterase and carbonic anhydrase enzymes inhibitors. J Biochem Mol Toxicol. 2017;31(11):e21973.

18. Ekiz M, Tutar A, Ökten S. Convenient synthesis of disubstituted tacrine derivatives via electrophilic and copper induced reactions. Tetrahedron. 2016;72(35):5323-30.

19. Valentini P, Rampa A, Bisi A, Andrisano V, Cavrini V, Fin L, et al. Acetylcholinesterase inhibition by tacrine analogues. Bioorg Med Chem Lett. 1997;7(20):2595-602.

20. Recanatini M, Cavalli A, Belluti F, Piazzi L, Rampa A, Bisi A. et al. SAR of 9-amino-1,2,3,4-tetrahydroacridine-based acetylcholinesterase inhibitors: synthesis, enzyme inhibitory activity, QSAR and structure-based CoMFA of tacrine analogues. J Med Chem. 2000;43(10):2007-18.

21. Çelik I, Akkurt M, Ekiz M, Ökten S, Tutar A, Ersanlı CC. 9-Amino-5,7-dibromo1,2,3,4-tetrahydroacridine hemihydrate. IUCrData. 2017;2(7):x171011.

22. Çelik I, Akkurt M, Ekiz M, Tutar A, Ökten S, Ersanlı CC. 11-[Bis(trimethylsilyl) amino]-2,4-bis(trimethylsilyl)-7,8,9,10-tetrahydro-6H-cyclohepta[1,2b] quinoline. IUCrData. 2017;2(6):x170888.

23. Ellman GL, Courtney KD, Andres V, Featherston RM. A new and rapid colorimetric determination of acetylcholinesterase activity. Biochem Pharmacol. 1961;7(2):88-95.

24. Erdemir F, Celepci DB, Aktaş A, Taslimi P, Gök Y, Karabıyık H, et al. 2-Hydroxyethyl substituted NHC precursors: Synthesis, characterization, crystal structure and carbonic anhydrase, a-glycosidase, butyrylcholinesterase and acetylcholinesterase inhibitory properties. J Mol Struct. 2018;1155:797-806.

25. Yamali C, Gül Hİ, Ece A, Taslimi P, Gülçin İ. Synthesis, molecular modeling and biological evaluation of 4-[5-aryl-3-(thiophen-2-yl)-4,5-dihydro-1Hpyrazol-1-yl] benzenesulfonamides toward acetylcholinesterase, carbonic anhydrase I and II enzymes. Chem Biol Drug Des. 2018;91(4):854-66.

26. Akıncıoğlu A, Akıncıoğlu H, Gülçin I, Durdağı S, Supuran CT, Göksu, S. Discovery of potent carbonic anhydrase and acetylcholine esterase inhibitors: Novel sulfamoylcarbamates and sulfamides derived from acetophenones. Bioorg Med Chem. 2015;23(13):3592-602.

27. Verpoorte JA, Mehta S, Edsall JT. Esterase activities of human carbonic anhydrases B and C. J Biol Chem. 1967;242(18):4221-9.

28. Küçük M, Gülçin I. Purification and characterization of carbonic anhydrase enzyme from black sea trout (Salmo trutta Labrax Coruhensis) kidney and inhibition effects of some metal ions on the enzyme activity. Environ Toxicol Pharm. 2016;44:134-9.

29. Lineweaver H, Burk D. The determination of enzyme dissociation constants. J Am Chem Soc. 1934;56(3):658-66.

30. Bradford MM. A rapid and sensitive method for the quantitation of microgram quantities of protein utilizing the principle of protein-dye binding. Anal Biochem. 1976;72(1-2):248-54.

31. Özgeriş B, Göksu S, Köse PL, Gülçin I, Salmas RE, Durdagi S, et al. Acetylcholinesterase and carbonic anhydrase inhibitory properties of novel urea and sulfamide derivatives incorporating dopaminergic 2-aminotetralin scaffolds. Bioorg Med Chem. 2016;24(10):2318-29.

32. Rajput AP, Kankhare AR. Synthetic utility of aza heterocyclics: A short review. Int J Pharm Sci Inv. 2017;6:19-25.

33. McKenna MT, Proctor GR, Young LC, Harvey AL. Novel tacrine analogues for potential use against Alzheimer's disease: potent and selective acetylcholinesterase inhibitors and 5-HT uptake inhibitors. J Med Chem. 1997;40(22):3516-23.

34. Korabecny J, Musilek K, Holas O, Binder J, Zemek F, Marek J, et al. Synthesis and in vitro evaluation of $\mathrm{N}$-alkyl-7-methoxytacrine hydrochlorides 
as potential cholinesterase inhibitors in Alzheimer disease. Bioorg Med Chem Lett. 2010;20(20):6093-5.

35. Topal F, Gülçin I, Daştan A, Güney M. Novel eugenol derivatives: potent acetylcholinesterase and carbonic anhydrase inhibitors. Int J Biol Macromol 2017;94:845-51.

36. Göçer H, Akıncıoğlu A, Göksu S, Gülçin I. Carbonic anhydrase inhibitory properties of phenolic sulfonamides derived from dopamine related compounds. Arab J Chem. 2017;10(3):398-402.
37. Arabacı B, Gülçin I, Alwasel S. Capsaicin: A potent inhibitor of carbonic anhydrase isoenzymes. Molecules 2014;19(7):10103-14.

38. Polat KL, Gülçin İ. Inhibition effects of some lignans on carbonic anhydrase, acetylcholinesterase and butyrylcholinesterase enzymes. Rec Nat Prod. 2017;11(6):558-61.

39. Rezai M, Bayrak Ç, Taslimi P, Gülçin I, Menzek, A. The first synthesis, antioxidant and anticholinergic activities of 1-(4, 5-dihydroxybenzyl) pyrrolidin-2-one derivative bromophenols including natural products. Turk $\mathrm{J}$ Chem. 2018;42(3):808-25.

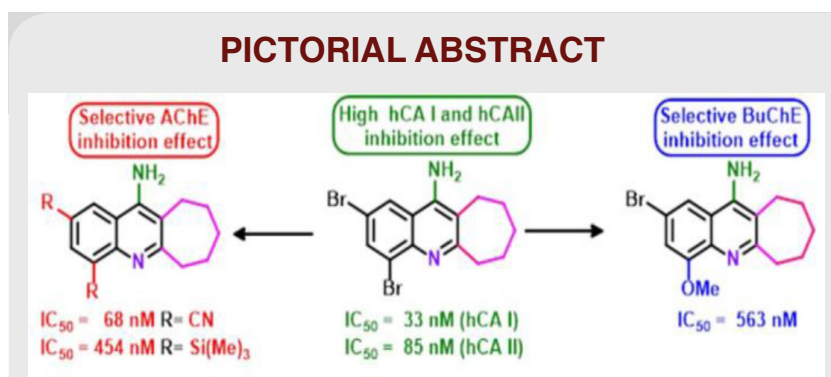

ABOUT AUTHORS

\section{SUMMARY}

- Disubstituted tacrine derivatives have selective inhibitory effects against cholinesterase enzymes. Bromotacrines bearing six or seven membered hydrocycle displayed high inhibition effect against cytosolic hCA I and hCA II enzymes. The cyano, silyl and thiomethly groups at C-6 and C-8 positions have significantly increased inhibitory effect of seven membered hyrocycle tacrines against AChE enzyme.

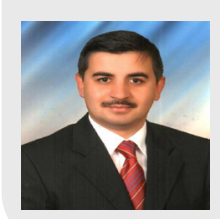

Dr. Salih ÖKTEN: He is an assistant professor in the Department of Mathematics and Science Education, Faculty of Education in Kırıkkale University. He has experience in synthesis and characterization of heterocycles such as quinoline, tacrine indenoquinoline etc. He has recently worked on derivation of quinoline, tacrine and their biological evaluation as anticancer antibacterial and enzyme inhibitors.

Cite this article: Ökten S, Ekiz M, Tutar A, Bütün B, Koçyigit ÜM, Topçu G, et al. SAR Evaluation of Disubstituted Tacrine Analogues as Promising Cholinesterase and Carbonic Anhydrase Inhibitors. Indian $\mathrm{J}$ of Pharmaceutical Education and Research. 2019;53(2):268-75. 